\title{
PERENIALISME DALAM PENDIDIKAN ISLAM
}

\author{
Moch Yasyakur, Kholid Sirojuddin, Wartono, Ari Julmanan \\ ${ }^{1}$ Sekolah Tinggi Agama Islam (STAI) Al-Hidayah \\ ${ }^{2}$ Sekolah Tinggi Agama Islam (STAI) Al-Aqiqah Al-Hasyimiyah \\ ${ }^{3,4}$ Sekolah Tinggi Agama Islam (STAI) Al-Hidayah \\ email: yasykurmuhammad@gmail.com \\ email:cangole45@gmail.com \\ email:wartono@staiabogor.ac.id \\ email:arijul.manan@yahoo.co.id
}

\begin{abstract}
ABSTRAK
Gaya hidup materialistik, ateistik, dan skeptis memberikan dampak pada munculnya pola hidup hedonistik, individualistik, karenanya problematika ini merupakan tantangan yang membutuhkan solusi. Salah satu pemecahan masalah tersebut pada sektor pendidikan adalah dengan menanamkan keperibadian atau membangun karakter melalui pendekatan perenialisme. Filsafat perenialisme memiliki konsep yang bersebrangan dengan materialis dan mekanis, perenialisme memiliki konsep pembinaan karakter holistik dan siklis yang sesuai dengan tujuan pendidikan, pembinaan akhlak mulia dan menjadikan insan kamil. Perenialisme dalam pendidikan merupakan warisan budaya generasi lampau untuk generasi baru, yakni berupa nilai-nilai abadi yang tidak dibatasi oleh ruang dan waktu, bertujuan membentuk karakter peserta didik disetiap waktu. Ontologi perenialisme berisikan pengertian akan benda individual, esensi, aksiden dan substansi. Pandangan aksiologi bahwa prilaku manusia berasal dari potensi pribadi manusia itu sendiri sebagai kodrat baik potensi positif maupun negatif. Perenialisme memiliki pandang masalah nilai berdasarkan pada prinsip supranatural, yakni menerima universal yang abadi. Masalah utama prinsip supernatural adalah tingkahlaku maka manusia sebagai subjek telah memiliki potensi kebaikan. Sebagai solusi bagi lembaga pendidikan dengan memilih metode yang mampu menanamkan doktrin kemuliaan hidup, berkarakter dan religius yakni melalui pendekatan perenialisme.
\end{abstract}

Kata kunci: perenialisme, pendidikan Islam, membangun, karakter

\section{A. PENDAHULUAN}

Perkembangan teknologi informasi, populasi manusia, timbulnya krisis multi dimensi, hingga akhirnya meretas pada dunia pendidikan adalah bagian dari permasalahan bangsa saat ini. Berbagai penyimpangan sosial dan prilaku tidak terpuji baik di lingkungan sekolah maupun masyarakat sering terjadi, seperti kasus asusila, narkoba, tawuran, dan lainlain. Fenomena ini dipengaruhi pula oleh gaya hidup materialistik, ateistik, dan skeptis akhirnya muncul pola hidup hedonistik, individualistik, permissif.

Problematika kehidupan saat ini merupakan tantangan yang membutuhkan solusi. Salah satu pemecahan masalah tersebut pada sektor pendidikan adalah dengan menanamkan keperibadian atau membangun karakter melalui pendekatan perenialisme.

Perenialisme adalah salah satu hasil pemikiran filsafat kuno yang masih memiliki relevansi terhadap 
perkembangan zaman dan dapat diaktualisasikan sepanjang zaman. Pendekatan perenial bertujuan untuk mengembangkan intelektual peserta didik melalui pengetahuan yang absolut dan universal, di antara manfaat pendekatan perenial dalam pendidikan adalah:

1. Kebenaran yang universal, tidak dipengaruhi oleh tempat, waktu, dan personal. Pendidikan merupakan upaya dalam mencari pemahaman atas kebenaran, sedangkam kebenaran itu sendiri merupakan fitrah dan absolut.

2. Kebebasan berpikir untuk mengembangkan pendidikan.

3. Upaya mewariskan budaya dan pemikiran tokoh atau ulama terdahulu.

\section{B. TINJAUAN TEORI}

Filsafat perenialisme ini, berasaskan pada kebudayaan yang mempunyai dua buah sayap, yaitu perenialisme yang bersifat theologis yang ada dalam pengayoman supermasi gereja katolik, khususnya menurut ajaran interpretasi Thomas Aquinas, dan perenialismesekuler, yakni yang berpegang pada ide dan cita filosofis Plato dan Aristoteles (Jalaludin dan Abdullah Idi:2002:90).
Bahwa Ide dan cita filosofi plato dan Aristoteles adalah meerupakan budi daya manusia dari dua sayap yang saling memberikan keyakinan dan melahirkan pemikiran teo-Thomisme sebagai sumber tuntunan -tuntunan cita kehidupan yang sejahtera bersifat kemulyaan dan keabadian, sebagaimana yang diungkapkan oleh Hamdani Ali berikut inidalam bukunya filsafat pendidikan.

Aristoteles mengembangkan Philosophia Perenis, yang sejauh mana seseorang dapat menelusuri jalan pemikiran manusia itu sendiri, S.T Thomas Aquinas telah mengadakan beberapa perubahan sesuai dengan tuntunan agama kristen tatkala agama itu datang. Kemudian lahir apa yang dikenal dengan nama Teo-Thomisme. TeoThomisme masih dalam bentuk awam maupun dalam faham gerejawi sampai tingkat kebijaksanaan, maka ia terkenal dengan nama perenialisme (Jalaludin dan Abdullah Idi:2002:90)

Aliran perenialisme dipakai untuk program pendidikan yang didasarkan atas pokok-pokok aliran Aristoteles dan S.T Thomas Aquinas. Dimana tokoh-tokoh ini timbul dari lingkungan agama katolik. Sedang kaitannya dengan pendidikan Pesantren didasarkan pada doktrin kepercayaan yang harus diamalkan, karna ajaran ini datang dari Tuhan. 
Perenialisme berpendapat bahwa apa yang dibutuhkan manusia terutama ialah jaminan bahwa reality is universal that is every where and at every moment the same, realita itu bersifat universal bahwa realita itu ada di mana saja dan sama di setiap waktu.

Dengan keputusan yang bersifat ontologisme kita akan sampai pada pengertian pengerian hakikat. Ontologi perenialisme berisikan pengertian, diantaranya ialah: benda individual, esensi, aksiden dan substansi.

Benda individual adalah benda yang sebagaimana nampak di hadapan manusia yang dapat ditangkap oleh indera manusia, seperti batu, kayu,dan lain-lain.

Esensi dari sesuatu adalah suatu kualitas tertentu yang menjadikan benda itu lebih baik intrinsik dari pada halnya, misalnya manusia ditinjau dari esensinya adalah berpikir.

Aksiden adalah keadaan khusus yang dapat berubah-ubah dan sifatnya kurang penting dibandingkan dengan esensialnya, misalnya orang suka barangbarang antik.

Substansi adalah suatu kesatuan dari tiap-tiap hal individu, dari yang khas dan yang universal baik yang material atau spiritual.substansi. (Jalaludin dan Abdullah Idi:2002:91).

Ada empat sebab (kausa) yang menjadi penyebab terjadinya sesuatu atau berlangsungnya sesuatu. Menurut Plato sebagai berikut:

Kausa materialis, yaitu bahan yang menjadi susunan sesuatu benda, misalnya telur, tepung dan gula untuk roti.
Kausa formalis, yaitu sesuatu dipandang dari formnya, bentuknya atau modelnya, misalnya bulat, kotak, dan lainlain.

Kausa efisien, yaitu gerakan yang digunakan dalam pembuatasesuatu cepat, lambat atau tergesa tergesa.

Kausa finalis, adalah tujuan atau akhir dari sesuatu, misalnya, tujuan

pembuatan sebuah patung (Imam Barnadib:66).

Apabila kausalitas diteruskan tinjuannya, maka kausalitas merupakan mata rantai yang tidak ada putusnya sebelum sampai kepada pertanyaan adanya penyebab pertama atau kausa prima. "Parenialisme dalam bidang ontologis berasal pada teologi yakni memandang bahwa realita sebagai substansi selalu cenderung bergerak atau berkembang dari potensialitas menuju aktualitas (teleologi)" (Maragustam:2010:112).

Perenialisme memerlukan adanya dalil-dalil yang logis, nalar, sehingga sulit untuk diubah atau ditolak kebenarannya. Menurut Aristoteles, prinsip-prinsip itu adalah:

Principium identitatis, yaitu identitas sesuatu. Contohnya apabila batu adalah batu dan tidak akan menjadi kayu

Principium contradiksionis, yaitu hukum kontradiksi (berlawanan, bertentangan). Suatu pernyataan pasti tidak mengandung sekaligus kebenaran dan kesalahan, pasti hanya mengandung satu kenyataan yakni benar atau salah. 
Principium exelusi tertii, yaitu tidak ada kemungkinan ketiga dalam satu dalil. Apabila pernyataan atau kebenaran pertama salah, pasti pernyataan kedua benar dan sebaliknya apabila pernyataan pertama benar pasti pernyataan yang berikutnya tidak benar.

Principium rationis sufisientis, prinsip ini pada dasarnya mengetengahkan apabila barang sesuatu dapat diketahui asal muasalnya pasti dapat dicari pula tujuan atau akibatnya (Imam Barnadib:1987:67).

\section{PEMBAHASAN}

\section{Pengertian Perenialisme}

Perenialisme adalah sebuah wacana filsafat kuno yang dapat diklaim tetap memiliki aktualisasi sepanjang zaman.

Konsep dalam perenialisme berbeda dengan konsep materialis dan mekanis, sedangkan perenialisme meiliki andalan karakter holistik dan siklis. Perenialisme juga terbuka menerima eksistensi segala aspek keduniaan, baik yang dapat diindra maupun yang tidak dapat dilihat oleh mata.

Dalam menyikapi krisis kehidupan manusia terutama pada bidang pendidikan maka perenialisme memberikan solusi dengan kembali kepada peradaban masa lampau yang dianggap ideal dan telah teruji keberhasilnya. Konsep pendidikan melalui pendekatan perenialisme dapat diterima pada lembaga pendidikan untuk mengatasi krisis moral, dengan meneladani generasi masa lampau.

Sebagai bagian dari aliran filsafat maka perenialisme memiliki susunan dan mempunyai kesatuan yang merupakan hasil pemikiran agar manusia memiliki bersikap yang baik, tegas dan lurus.

Perenialisme diambil dari kata perenial diartikan sebagai "continuing throughout the whole year atau lasting for a very long time (abadi atau kekal terus menerus tanpa akhir) adalah makna lugas dari aliran perenialisme" (Muhmidayeli:2011:158) kata perenialisme mengandung kepercayaan filsafat yang berpegang pada nilai dan norma yang bersifat kekal abadi.

Esensi kepercayaan filsafat perenial adalah ajaran yang berpegang pada nilai atau norma yang bersifat abadi, perenialisme memiliki arti everlasting atau abadi. Dapat disimpulkan bahwa pendekatan perenialisme adalah suatu metode penanaman nilai kebaikan manusia yang kokoh, kuat dan abadi kepada peserta didik sehingga dapat memahami dan meyakini kehidupan mulia serta mampu mengimplementasikannya dalam kehidupan sehari-hari.

\section{Sejarah Filsafat Perenialisme}

Istilah Perenialisme menurut Syed Muhammad Hossen Nasr seperti yang 
dikutip oleh Muhmidayeli, pertama kali dicetuskan oleh Agustinus di dalam buku karangannya yaitu yeitu De perenila Philosophia yang diterbitkan pada tahun 1540, kemudian istilah perenialisme ini lebih popular di tangan Leibniz yang digunakan dalam suratnya kepada temannya Remundo yang ditulisnya pada tahun 1715 (Muhmidayeli:2011:160).

Perenialisme berasal dari bahasa latin, yaitu dari akar kata perenis atau perennial (bahasa Inggris) yang berarti tumbuh terus menerus melalui waktu, hidup terus dari waktu ke waktu atau abadi (Teguh Wangsa Gandhi HW:2011:163).

Hampir di setiap letelatur mengatakan "mulai lahirnya perenialisme pada abad ke 20, namun Emanuel Wora dalam bukunya berjudul Perenialisme Kritik Atas Modernisme Dan Postmodernism, mengatakan bahwa "Perenialisme lahir pada tahun 1930-an sebagai suatu reaksi terhadap pendidikan progresif" (Emanuel Wora:2006:17) perenialisme muncul sebagai konter terhadap pandangan progresivisme yang memiliki misi penekanan perubahan untuk sesuatu yang baru.

Perenialisme muncul karena situasi dunia penuh dengan kekacauan, buruknya prilaku manusia, dan ketidakteraturan, terutama merosotnya moral, intelektual dan sosio-kultural. Perenialisme membenahi dan penyelamatannya untuk kemaslahatan manusia khususnya pada generasi penerus.

\section{Esensi Aliran Filsafat Perenialisme}

Perenialisme merupakan aliran filsafat pendidikan yang didukung oleh filsafat idealisme, sekilas hampir sama dengan pendidikan pesantren. Konsep perenialisme dalam pendidikan merupakan warisan budaya generasi lampau kepada generasi baru, yakni berupa nilai-nilai abadi tidak dibatasi oleh ruang dan waktu. Pada lingkungan Pesantren tujuan pendidikan perenialisme bersifat pasti dan abadi karena berasal dari Tuhan yakni membentuk karakter peserta didik disetiap waktu.

Kondisi sekarang ini tidak sedikit lembaga pendidikan yang minim outputnya dalam perilaku-perilaku positif yang berakibat merebaknya penyimpangan sosial dan mengganggu kehidupan masyarakat sekitarnya. Kegagalan lembaga pendidikan berakibat pada ketidakmampuan mengendalikan krisis moral anak-anak bangsa, kegagalan tersebut umumnya karena tidak diterapkannya kurikulum penanaman moral secara sungguh-sungguh melalui pendekatan perenialisme. Padahal sejarah telah membuktikan bahwa perenialisme mampu mensikapi krisis dan telah 
berkontribusi dalam perwujudan peradaban yang madani.

Untuk memahami adanya hubungan kekuatan ajaran perenialisme antara empirik dan spiritual ditinjau dari beberapa sudut pandang, misalnya pandangan ontologi perenialisme bahwa apa yang dibutuhkan manusia terutama ialah realita yang memiliki sifat universal bahwa realita itu ada di mana saja dan sama disetiap waktu. Ontologi perenialisme berisikan pengertian akan benda individual, esensi, aksiden dan substansi. Benda individual adalah benda yang sebagaimana nampak di hadapan manusia yang dapat ditangkap oleh indera manusia, esensi dari sesuatu adalah kualitas tertentu yang menjadikan benda itu lebih baik intrinsik dari pada halnya, misalnya manusia ditinjau dari esensinya adalah berpikir. Aksiden adalah keadaan khusus yang dapat berubah-ubah dan sifatnya kurang penting dibandingkan dengan esensialnya. Substansi adalah kesatuan dari tiap hal individu dari yang khas maupun universal baik yang material atau immateril.

Ada empat kausa atau sebab terjadinya sesuatu atau berlangsungnya sesuatu. Plato dalam fisika menerangkan bahwa istilah-istilah yang menjelaskan tentang adanya garis perjalanan suatu benda yang digunakan sebagai dasar untuk mengadakan penemuan mengenai suatu benda. Kausa tersebut seperti:

kausa materialis, yaitu bahan yang menjadi susunan sesuatu benda, kausa formalis, yaitu sesuatu dipandang dari formnya, bentuknya atau modelnya, kausa efisien yaitu gerakan yang digunakan dalam pembuatan sesuatu, kausa finalis adalah tujuan atau akhir dari sesuatu.

Apabila kausalitas diteruskan tinjuannya, maka kausalitas merupakan mata rantai yang tidak ada putusnya sebelum sampai kepada pertanyaan adanya penyebab pertama atau kausa prima. "Parenialisme dalam bidang ontologis berasal pada teologi yakni memandang bahwa realita sebagai substansi selalu cenderung bergerak atau berkembang dari potensialitas menuju aktualitas (teleologi)"

(Maragustam:2010:112).

Hubungan manusia dengan aktualitas adalah bahwa manusia mempunyai potensialitas yang berubah menjadi aktualitas. Di samping asas teleologi yang merupakan aktualisasi dari potensialitas, terdapat asas potensialitas supernatural dimana tujuan akhir dari supernatural adalah Tuhan. Menurut perenialisme membutuhkan suatu yang logis, nalar, sehingga sulit untuk diubah atau ditolak kebenarannya. Menurut Aristoteles, prinsip-prinsip itu adalah: identitas 
sesuatu seperti batu tidak akan menjadi kayu, kontradiksi bahwa suatu pernyataan pasti tidak mengandung sekaligus kebenaran dan kesalahan, pasti hanya mengandung satu kenyataan yakni benar atau salah, tidak adanya kemungkinan ketiga dalam satu dalil apabila pernyataan atau kebenaran pertama salah, pasti pernyataan kedua benar dan sebaliknya, dan sesuatu yang dapat diketahui asal muasalnya pasti dapat dicari pula tujuan atau akibatnya.

\section{Pandangan Aksiologi Perenialisme}

Pandangan aksiologi bahwa prilaku manusia berasal dari potensi pribadi manusia itu sendiri sebagai kodrat baik potensi positif maupun negatif. Prilaku manusia yang mengandung nilai-nilai kebaikan adalah searah dengan sifat pikiran dan hakikat jiwa manusia yaitu spiritual.

Perenialisme memiliki pandang masalah nilai berdasarkan pada prinsip supranatural, yakni menerima universal yang abadi. Masalah utama prinsip supernatural yakni dalam tingkah laku manusia maka manusia sebagai subjek telah memiliki potensi-potensi kebaikan.

Dengan tertanamnya doktrin-doktrin kemulyaan yang datang dari Tuhan, jiwa manusia akan semakin dekat dengan Tuhan dan selanjutnya ajaran-ajaran Tuhan bukan lagi merupakan intruksi melainkan menjadi kebutuhan manusia perdetik dalam kehidupannya. Jika ajaran Tuhan sudah menjadi kebutuhan hidup sehari-hari, maka terjadilah seluruh gerakan atau prilaku dalam hidupnya selalu mengacu pada petunjuk-petunjuk ajaran Tuhan, dalam ajaran Islam dikenal ajaran yang ada pada Al-Qur'an dan AlHadits.

Ketinggian moral adalah kebajikan yang merupakan pembentukan kebiasaan, yang merupakan dasar dari kebajikan intelektual. Ketinggian intelektual dibentuk oleh pendidikan dan pengajaran. Kebajikan intelektual didasari oleh pertimbangan dan pengawasan akal. Pada perenialisme estetika digolongkan kedalam filsafat praktis. Kesenian sebagai salah satu sumber keindahan adalah suatu kebajikan intelektual yang bersifat praktis filosofis.Dengan memperhatikan hal ini maka pendidikan yang berorientasi pada potensi dan masyarakat dapat terpenuhi.

\section{Prinsip-Prinsip Perenialisme}

Prinsip dasar pendidikan perenialisme adalah mendekatkan anak didik untuk menemukan dan menginternalisasikan kebenaran abadi, karena kebenaran abadi mengandung sifat universal dan tetap. Kebenaran tersebut dapat diperoleh hanya dapat diperoleh melalui latihan intelektual yang membuat pikirannya tertata dan tersistematis secara 
baik. Di dalam dunia filsafat pendidikan Islam kebenaran yang abadi tidak hanya diperoleh melalui latihan intelektual, tapi melalui latihan intuisi. Pengetahuan adalah sumber kebenaran, kebenaran selamanya memiliki kesamaan. Pendidikan harus mencari pola agar peserta didik dapat menyesuaikan diri, keseimbangan antara kebenaran dunia kebenaran-kebenaran yang hakiki.

Proses pendidikan tidak selalu transfer ilmu tetapi juga tranformasi ilmu dan internalisasi atau penanaman nilai. Prinsip-prinsip dasar tersebut kemudian dikembangkan oleh Sayyed Husein Nasr, seorang filosof Islam kontemporer yang mengatakan bahwa manusia memiliki fitrah yang sama yang berpangkal pada asal kejadiannya yang fitri yang memiliki konsekwensi kepada watak kesucian dan kebaikan, sifatnya tidak akan pernah berubah karena prinsip-prinsipnya mengandung kontinuitas dalam setiap ruang dan waktu.

Program pendidikan yang ideal menurut perenialisme adalah berorientasi pada potensi dasar agar kebutuhan yang ada pada setiap lapisan masyarakat dapat terpenuhi. Pandangan aliran di atas ada kesamaan dengan pendidikan Islam karena mengakui adanya potensi dasar yang dimiliki manusia semenjak dilahirkan yang dikembangkan melalui proses pendidikan. Makna hakiki dari belajar, menurut aliran ini adalah belajar untuk berpikir.

\section{Teori dasar dalam Belajar Menurut Perenialisme}

Penganut perenialisme sependapat bahwa "latihan dan pembinaan berpikir (mental disiplin) adalah salah satu kewajiban tertinggi dari belajar, atau keutamaan dalam proses belajar. Karena itu teori dan program pendidikan pada umumnya dipusatkan kepada pembinaan kemampuan berpikir (Teguh Wangsa Gandhi HW:2011:180).

a. Rasionalitas dan asas kemerdekaan.

Asas berpikir dan kemerdekaan harus menjadi tujuan utama pendidikan, otoritas berpikir harus disempurnakan sesempurna mungkin. Makna kemerdekaan pendidikan ialah membantu manusia untuk menjadi dirinya sendiri (be him-self), sebagai essential-self yang membedakannya daripada makhluk- makhluk lain. Fungsi belajar harus diabdikan bagi tujuan ini, yaitu aktualitas manusia sebagai makhluk rasional yang dengan itu bersifat merdeka (Teguh Wangsa Gandhi HW:2011:180). 
b. Learning to reason (belajar untuk berpikir)

Perenialisme tetap percaya dengan asas pembentukan kebiasaan dalam permulaan pendidikan anak. Kecakapan membaca, menulis dan berhitung merupakan landasan dasar. Dan berdasarkan pentahapan itu, maka learning to reason menjadi tujuan pokok pendidikan sekolah menengah dan pendidikan tinggi (Teguh Wangsa Gandhi HW:2011:180).

c. Belajar sebagai persiapan hidup Bagi Thomisme, belajar untuk berpikir dan belajar untuk persiapan hidup (dalam masyarakat) adalah dua langkah pada jalan yang sama, yakni menuju kesempurnaan hidup, kehidupan dunia ataupun surgawi.

d. Learning through teaching (belajar melalui pengajaran)

Adler membedakan antara learning by instruction dan learning by discovery, penyelidikan tanpa bantuan guru. Sebenarnya learning by instruction adalah dasar dan menuju learning by discovery, sebagai self education. Menurut perenialisme, tugas guru bukanlah perantara antara dunia dengan jiwa anak, melainkan guru juga sebagai murid yang mengalami proses belajar sementara mengajar (Teguh Wangsa Gandhi HW:2011:181).

\section{Implikasi Filsafat Perenialisme dalam Pendidikan}

Perenialisme memandang pendidikan sebagai proses mengembalikan keadaan sekarang. Perenialisme memberikan sumbangan yang berpengaruh, baik berupa teori maupun praktik bagi kebudayaan dan pendidikan zaman sekarang. Perenialisme merupakan aliran filsafat yang berdasarkan pada kesatuan, bukan mencerai-beraikan, menemukan persamaan-persamaan, bukan membanding-bandingkan, serta memahami isi, bukan melihat luar atas berbagai aliran dan pemikiran.

Perenialisme mensikapi pendidikan di abad 21 ini tetap relevan dengan azas pendidikan yaitu azas berfikir dan kemerdekaan, namun bertujuan menjunjung tinggi kemuliaan manusia.

"The vision for 21st Century learning developed offers a holistic and syistemic view of how we can reconcepetualilize and reinvigorate public education, bringing together all the elements - 21st century student outcomes and 21 st century education support systems - into a unified framework" (James Bellanca, Ron 
Brandt:2010:14). Dijelaskan bahwa visi belajar di abad 21 secara sistemik dan holistik untuk memperkuat pendidikan di tengah masyarakat agar bertabat. Sudah di maklum bahwa holistik adalah suatu filsafat pendidikan berasal dari pemikiran. Bahwa pada dasarnya seorang individu dapat menemukan identitas, tujuan dan makna hidup melalui hubungannya dengan masyarakat, nilai-nilai spiritual. dan lingkungan alam, jadi secara historis, pendidikan holistik sebetulnya bukan hal yang baru.

Bagi perenialis, nilai-nilai kebenaran bersifat universal dan abadi. Inilah yang menjadi tujuan pendidikan sejati. Oleh karena itu, tujuan pendidikan adalah membantu peserta didik menyiapkan dan menginternalisasikan nilai-nilai kebenaran yang abadi agar mencapai kebijakan dan kebaikan dalam hidup.

Sekolah merupakan lembaga latihan elite intelektual yang mengetahui kebenaran dan suatu waktu akan meneruskannya kepada generasi pelajar yang baru. Sekolah adalah lembaga yang berperan mempersiapkan peserta didik atau orang muda untuk terjun ke dalam kehidupan. Sekolah bagi perenialis merupakan peraturan-peraturan yang merupakan tempat peserta didik berkenalan dengan hasil yang paling baik dari warisan sosial budaya. Sekolah menjadi tempat utama dalam pendidikan yang mempersiapkan anak didik ke arah keemasan memalui akalnya dengan memberikan pengetahuan.

a. Kedudukan siswa generasi penerus

Kaum perenialis berpendapat bahwa siswa adalah subyek sekaligus inti dalam pelaksanaan pendidikan, dan guru hanya bertugas menolong membangkitkan potensi yang dimiliki anak didik yang masih tersembunyi agar menjadi aktif dan nyata, bukan membentuk atau memberikan kemampuan kepada anak didik.

b. Peranan Guru Sebagai Tokoh Sentral

Rasio merupakan atribut manusia yang paling tinggi. Manusia harus menggunakannya untuk mengarahkan sifat bawaannya, sesuai dengan tujuan yang ditentukan. Manusia adalah bebas, namun mereka harus belajar, untuk memperhalus pikiran dan mengontrol seleranya. Apabila anak gagal dalam belajar, guru tidak boleh dengan cepat meletakkan kesalahan pada lingkungan yang tidak menyenangkan, atau pada 
rangkaian peristiwa psikologis yang tidak menguntungkan. Guru harus mampu mengatasi semua gangguan tersebut, dengan melakukan pendekatan secara intelektual yang sama bagi semua siswa. Dan tidak ada anak yang diizinkan untuk menentukan pengalaman pendidikannya yang ia inginkan.

c. Metode

Metode pendidikan atau model belajar utama yang digunakan oleh perenialis adalah membaca dan diskusi, yaitu membaca dan mendiskusikan karya-karya yang tertuang dalam the greats book dalam rangka mendisiplinkan pikiran.

Peranan guru bukan sebagi perantara antara dunia dengan jiwa anak, melainkan guru juga sebagai murid yang mengalami proses belajar sementara. Guru mengembangkan potensi-potensi self-discovery. Ia juga melakukan moral authority (otoritas moral) atas murid-muridnya karena ia seorang professional yang qualified dan superior dibandingkan dengan muridnya. Guru itu harus mempunyai aktualitas yang lebih dan pengetahuan yang sempurna

(Teguh Wangsa Gandhi HW:2011:17).

Metode pembelajaran pada intinya berfokus pada proses belajar. Tuntutan tertinggi dalam belajar menurut Perenialisme, adalah latihan dan disiplin mental. Metode pembelajaran haruslah mengarah kepada tuntunan tersebut. Menurut Teguh Wangsa bahwa tuntunan belajar dapat mengacu pada teori dasar dalam belajar menurut perenialisme, seperti pembinaan belajar, Azas kemerdekaan berfikir, belajar untuk berfikir, belajar sebagai persiapan hidup, belajar melalui pengajaran, dan guru terus mengembangkan potensi.

d. Penerapan Teori Perenialisme dalam Kurikulum

Kurikulum menurut kaum perenialis harus menekankan pertumbuhan intelektual pada seni dan sains. Dua dari pendukung filsafat perenialis adalah Robert Maynard Hutchins, dan Mortimer Adler. Sebagai rector the University of Chicago, Hutchin (1963) menegembangkan suatu kurikulum mahasiswa $\mathrm{S} 1$ berdasarkan penelitan terhadap 
Buku besar bersejarah (Great

Book) dan pembahasan buku-buku

klasik. Kegiatan ini dilakukan

dalam seminar-seminar kecil.

Kurikulum perenialis Hutchins

didasarkan pada tiga asumsi mengenai pendidikan. Pertama, pendidikan harus mengangkat pencarian kebenaran manusia yang berlangsung terus menerus.

Kebenaran apapun akan selalu benar dimanapun juga. Kebenaran bersifat universal dan tak terikat waktu. Kedua, karena kerja pikiran adalah bersifat intelektual dan memfokuskan pada gagasan gagasan, pendidikan juga harus memfokuskan pada gagasangagasan pengolahan rasionalitas manusia adalah fungsi penting pendidikan. Ketiga, pendidikan harus menstimulus peserta didik untuk berfikir secara mendalam mengenai gagasan-gagasan signifikan.

1) Pendidikan Dasar dan Menengah

Pendidikan sebagai persiapan berbeda dengan progresivisme tentang "education as preparation". Progresivisme pandangan bahwa sekolah (pendidikan) adalah persiapan untuk kehidupan.

Tetapi

Perenialisme berpendapat bahwa pendidikan adalah persiapan bagi kehidupan di dalam masyarakat. Dasar pandangan ini berpangkal pada ontologi, bahwa anak ada dalam fase potensialitas menuju aktualitas, menuju kematangan.

Kurikulum

Sekolah

Menengah Prinsip kurikulum pendidikan dasar, bahwa pendidikan sebagai persiapan, berlaku pula bagi pendidikan menengah. Perenialisme membedakan kurikulum pendidikan menengah antara program, "general education" dan pendidikan kejuruan, yang terbuka bagi anak 12-20 tahun.

2) Pendidikan Tinggi dan Adult Education

Kurikulum "general education" dipersiapkan untuk pendidikan tinggi. Pendidikan tinggi sebagai lanjutan pendidikan menengah dengan program general education yang telah selesai disiapkan, bagi umur 21 tahun sebab 
dianggap

telah

cukup

mempunyai

kemampuan

melaksanakan

program

pendidikan tinggi. Pendidikan

tinggi pada prinsipnya

diarahkan untuk mencapai

tujuan kebajikan intelektual yang disebut "The intellectual love of good". Kurikulum untuk meningkatkan pengetahuan yang telah dimilikinya menetralisir pengaruh-pengaruh jelek yang ada. Nilai utama pendidikan orang dewasa secara filosofis ialah mengembangkan sikap bijaksana, guna reorganisasi pendidikan anak-anaknya, dan membina kebudayaannya. Malahan Hutchins mengatakan, pendidikan orang dewasa adalah jalan menyelamatkan kehidupan bangsa-bangsa.

Kurikulum pendidikan bersifat subject centered, berpusat pada materi pelajaran. Materi pelajaran bersifat seragam, universal dan abadi. Selain itu, materi pelajaran terutama harus terarah kepada pembentukan rasionalitas manusia sebab demikianlah hakikat manusia. Mata pelajaran yang mempunyai status tertinggi adalah mata pelajaran yang mempunyai "rational content" yang lebih besar. Kurikulum berfokus pada pelajaran sastra, matematika, bahasa dan humonaria, termasuk sejarah (liberal art). Sedangkan sumber dan cara mempelajari seni liberal tersebut adalah dengan mempelajari The Greats Book. Berkenaan dengan kurikulum, hanya satu pertanyaan yang harus diajukan, yaitu: apakah para pesrta didik memperoleh muatan yang merepresentasikan usahausaha yang paling tinggi dalam bidang itu?

Dua dari pendukung filsafat perenilais adalah Robert Maynard Hutchins, dan Mortimer Adler. Sebagai Rektor the University of Chicago, Hutchins (1963) mengembangkan suatu kurikulum mahasiswa $\mathrm{S} 1$ berdasarkan buku besar bersejarah (Great books) dan pembahasan buku-buku klasik. Kegiatan ini dilakukan dalam seminar-seminar kecil. Kurikulum perenialis Hutchins didasarkan pada tiga asumsi mengenai pendidikan:Pendidikan harus mengangkat pencarian kebenaran manusia yang berlangsung terus menerus. Kebenaran 
apapun akan selalu benar dimanapun juga.

Kebenaran bersifat universal dan tak terikat waktu.

Karena kerja pikiran adalah bersifat intelektual dan memfokuskan pada gagasan-gagasan, pendidikan juga harus memfokuskan pada gagasan-gagasan. Pengolahan rasionalitas manusia adalah fungsi penting dalam pendidikan dan "pendidikan harus menstimulasi para mahasiswa untuk berfikir secara mendalam mengenai gagasan-gagasan signifikan.

1. Pendidikan dalam perenialisme, merupakan suatu jalan ataupun proses untuk mengembalikan keadaan dunia dewasa ini kepada masa lampau dan memberikan sumbangan yang sangat berpengaruh baik teori maupun praktik bagi kebudayaan dan pendidikan zaman sekarang.

2. Terkait dengan pendidikan, bahwasanya perenialisme beranggapan bahwa setiap pendidikan memiliki suatu tujuan yang kekal dan abadi, dan merupakan suatu kesatuan yang sama sehingga tidak timbul perbedaan dan perselisihan didalamnya. Hal tersebut merupakan suatu upaya agar segala kekrisisan yang terjadi pada saat ini dapat teratasi. Karena segala sesuatu yang tetrus menerus berkembang dengan munculnya gagasan baru yang tidak didasari oleh sistem pengetahuan yang absolut dan banyaknya manusia yang kurang bahkan tidak peduli akan perubahanperubahan tersebut, maka tujuan yang dicapaipun semakin jauh dari kenyataan.

3. Segala aspek pendidikan yang terjadi dimasa lampau dan masa sekarang merupakan suatu kesatuan yang kedua-duanya sangat berarti dan sama-sama memiliki kelemahankelemahan dan kelebihan-kelebihan tertentu dari sudut pandang dan pendekatan yang berbeda. Oleh karenanya dalam menjalani hidup dimasa era-modern ini, segala yang baik yang didapat baik suatu paradigma ataupun ide-ide dan gagasan yang didapat pada masa lampau dan sekarang, hendaklah diambil dari segi positifnya, tanpa mengurangi nilai-nilai dan normanorma yang terkandung didalamnya.

4. Beberapa Pandangan Para Tokoh Tentang Perenialisme

Pandangan Perenialisme terhadap manusia,pendidikan, Kurikulum dan Pembelajaran.

Filsafat pendidikan memberi manfaat diantaranya adalah a) Dapat menentukan arah akan dibawa kemana anak-anak 
melalui pendidikan, b) filsafat pendidikan akan memberi arah atas usaha-usaha pendidikan, c) memungkinkan bagi pendidik untuk menilai keberhasilan usahanya, d) memberi dorongan bagi usaha-usaha pendidikan (Dadang Sukirman dan Asra: 2010:18).

\section{KESIMPULAN}

Perenialisme merupakan sebuah wacana filsafat kuno yang bersebrangan dengan konsepsi modernisme dan menolak progresivisme. Perenialisme memandang realita yang terjadi pada saat ini harus di kembalikan kepada masa lampau. Karena perenialisme berpegang pada nilai-nilai atau norma-norma yang bersifat kekal atau abadi. Nilai-nilai dan norma-norma tersebut berupa suatu Ide dan gagasan yang telah terbukti keabsahan dan kegunaannya karena mampu bertahan seiring perjalanan waktu. Perenialisme mengembalikan konsep hidup kepada masa lampau bukan untuk bernostalgia tetapi berdasar pada keyakinan bahwa kepercayaan prinsip-prinsip aksiomatis yang berguna pada zaman sekarang karena tidak terikat oleh waktu. Filsafat Perenialisme beranggapan bahwa betapa pentingnya pembentukan kebiasaan dalam pendidikan sekarang yang didasarkan pada kebiasaan dan kebudayaan pada masa lampau yang memiliki nilai dan idealitas serta tetap memiliki kegunaan untuk kehidupan masa sekarang. Philosophia Perenis memiliki dua aspek kekuatan dalam menanamkan ajaran kemuliaan yaitu kekuatan secara empirik dan kekuatan secara metafisika. Kekuatan empirik untuk memperkuat pengetahuan dan pengalaman, sedangkan metafisika sebagai kekuatan spiritual.

Permasalah dalam pendidikan membutuhkan pemikiran yang mendalam dan mengakar pada inti permasalahan, perlu dipecahkan secara sistematis dan bersifat menyeluruh pada aspek-aspek yang terkait dengan pendidikan, baik masalah sosial, politik, ekonomi, budaya dan keamanan. Filsafat sangat dibutuhkan untuk memberi solusi bagi permasalahan pendidikan. Perenialis dapat menjadi solusi untuk kembali kepada peradaban masa lalu yang dianggap ideal, sejalan dengan filsafat idealisme Plato. Perenialisme merupakan aliran filsafat yang integral, komprehensif dan solutif agar manusia memiliki sikap yang baik, tegas dan lurus. Pendiddikan Pesantren dan sekolah berbasis agama Islam menjadi contoh dalam pelaksanaan konsep pendidikan karakter, akhlak mulia, keselamatan di dunia dan akhirat.

Kurikulum pendidikan formal baiknya mempertimbangankan faktor lingkungan keluarga dan masyarakat. 
Melibatkan orang tua murid dan tokoh masyarakat dalam merumuskan kurikulum pendidikan menjadi suatu keniscayaan, terlebih pada lembaga pendidikan memposisikan kurikulum agama sebagai basisnya. Maka solusi bagi lembaga Pendidikan dengan memilih metode yang mampu menanamkan doktrin kemuliaan hidup, berkarakter dan religius yakni melalui pendekatan perenialisme.

Al-Qur'an merupakan sumber solusi dari berbagai macam krisis moral manusia, maka menjadi tugas para pendidik mewujudkan Perenialisme sebagai pendekatan pendidikan karakter. Seperti pendidikan pesantren tidaklah lepas dari penanam-penanam hidup kekinian dan masa yang akan datang dengan konsep kemuliaan, atau mencetak generasi yang sholeh. Konsep ini sejalan dengan perenialisme dalam pendidikan dengan menanamkan nilai-nilai kemuliaan bagi dirinya dan di lingkungan masyarakat.

\section{DAFTAR PUSTAKA}

Moh. Yamin. (2013). Idiologi dan Kebijakan Pendidikan, MenujuPendidikan yang Beridiologis dan berkarakter. Malang: Madani.

Wahbah Az-Zuhaili. (2016). Tafsir AlMunir, Aqidah, Syari'ah, dan Manhaj. Jakarta: Gema Insani.
M. Quraish Shihab. (2012). Tafsir AlMishbah, Pesan, Kesan, dan Keserasian Al-Qur'an. Ciputat : Lentera Hati.

Muhajir. (2013). Filsafat Pendidikan Islam Syi'ah. Yogyakarta:Pustaka Pelajar.

Sutrisna dan Mahyidin Al-Barobis. (2012). Pendidikan Islam Berbasis Problem Sosial. Jogjakarta: Ar- Ruz Media.

Ishom El-Saha dan Saiful Hadi. (2011). Sketsa Al-qur'an; Tempat, Tokoh Nama dan Istilah dalam Al-Qur'an. t.tp: Listafariska Putra.

Departemen Pendidikan Nasional. (2008). Kamus Besar Bahasa Indonesia. Jakarta: PT Gramedia Pustaka Utama.

Muhmidayeli. (2011). Filsafat Pendidikan. Bandung: Refika Aditama.

Teguh Wangsa Gandhi HW. (2011). Filsafat Pendidikan. Yogyakarta:ArRuzzmedia.

Maragustam. (2010). Filsafat Pendidikan Islam. Yogyakasrta: Nuhalitera.

Wesley Null. (2011). Curriculum: From Theory to Practice. Rowman \& Littlefield Publishers. New York : INC. lanham.

James Bellanca, Ron Brandt. (2010). 21st Century Skills: Rethinking How Students Learn. Amerika: Solution Tree Press.

Dadang Sukirman dan Asra. (2010). Landasan Pengembangan Kurikulum, dalam Kurikulum dan Pembelajaran. Jakarta: Rajawali Press.

Redja Mudyahardjo. (2013). Pengantar Pendidikan: Sebuah Studi Awal tentang Dasar-dasar Pendidikan Pada umumnya dan Pendidikan di Indonesia. Jakarta: PT RadjaGrafîndo Persada. 
Undang Ahmad Kamaluddin. (2012). Fîlsafat Manusia. Bandung: Pustaka Setia.

Abdurrahman Al-Nahlawi. (2007). Ushul Al-Tarbiyat Al-Islamiyah wa Asalibaha fi Al-bait wa Al-Madrasah wa Al-Mujtama. Baerut : Dar el-Fikr.

Muhammad Munir Mursyi. (2005). AlTarbiyat Al-Islamiyah: ushulaha wa tathawwaraha fi Bilad al-Arabiyah. t,tp : Alam Al-Kitab.

Abu Muhammad Makki ibn Abi Thalib Hamus ibn Muhammad ibn Muhtar Al-Qaisy. (2008). Al-Hidayah Ila Bulugh Al-Nihayah fi Ma'ani ilm AlQur'an wa Tafsirih wa Ahkamih wa Jumali Funun Ulumih, Jami'at Syariqah, Majmu'at Buhuts Al-Kitab wa Al-Sunnah. t.tp : tp.

Buku Permendiknas RI No. 22,23,24. Jakarta: Depdiknas RI Tahun 2008.

Buku. (2009). UU Guru dan Dosen, No. 14 Tahun 2005. Bandung: Penerbit Jabar Education and Entrepreneur (JEEC).

Undang-Undang RI No. 20 Tahun 2003 bab.1, UU Sistem Pendidikan Nasional.

Muhammad As-said. (2011). Filsafat Pendidikan Islam. Yogyakarta: Mitra Pustaka.

Muhammad Ali Faisal. (2012). The Challenges and Opportunities of Impementing and Islam-Bassed Education System in Canada's Multicultural Society: The Case of British Columbia Muslim School. Durham Theses. t.tp : Durham University.

Uyoh Sadullah. (2-14). Pengantar Filsafat Pendidikan. Bandung: Alfabeta.

Kementerian Pendidikan dan Kebudayaan Republik Indonesi. (2011). Himpunan undang-undang dan
Peraturan Pemerintah Bidang Pendidikan. Kemendikbud.

Anis Baswedan. (2012). Kualitas Guru adalah Kunci Utama Kemajuan Bangsa. dalam buku Gurunya Manusia. Bandung : kaifa Learning.

Munir Abdullah. (2010). Pendidikan Karakter: membangun karakter Anak sejak dari rumah. Jogjakarta: Pedagogia.

Agus Hasan Bashori. (2013). Pendidikan Karakter Berbasis Sunnah Nabi. Malang.

Thomas Liickona. (2012). Educating For Character: Mendidik Untuk membentuk Karakter : bagaimana Sekolah dapat Memberikan Pendidikan Tentang Sikap Hormat dan Tanggung Jawab. Jakarta: Penerbit Bumi Aksara.

HE Mulyasa. (2011). Manajemen Pendidikankarakter. Jakarta: Penerbit Bina Aksara.

Marvin W. Berkowitz. (2012). The Science of Character Education. Damon: Hoover Press.

Doni Koesoema. (2011). Pendidikan Karakter, Strategi mendidik Anak di Zaman Modern. Jakarta : PT Grasindo.

Dono Koesoema. (2013). Pendidikan Kasrakter di zaman keblinger: Membangun visi Guru dalam Pengembangan Pendidikan Karakter. Jakarta : PT Grasindo.

Kementrian Pendidikan dan Kebudayaan. (2011). Himpunan UndangUndangan dan Peraturan pemerintah Bidang pendidikan. Jakarta: Kemendiknas.

Kementrian Pendidikan dan Kebudayaan Republik Indonesia, Buku Induk Kebijakan Nasional Pembangunan karakterBangsa 2010-1025 
Tim Penulis badan Penulisan dan Pengembangan Kementerian Agama republik Indonesia. (2013). Pendidikan Karakter di Madrasah Ibtidaiyah Unggulan. Jakarta: Balitbang Kemenag.

Badan Penulisan dan pengembangan, Pusat Kurikulum dan Perbukuan, Kementerian pendidikan Nasional. (2011). Pedoman Pelaksanaan Pendidikan karakter. Jakarta: Kemendiknas.

Maksudin. (2013). Pendidikan Non Dikotomik. Yogyakarta: Pustaka Belajar.

Mansur Muslich. (2011). Pendidikan Karakter, Menjawab Tantangan krisis Multidimensial. Jakarta: PT Bumi Aksara.

Risa Rahayu. (2011). Lingua Franca. Pendidikan Karakter: Pengertian, Implentasi dan Metodologi, 1(1).

Dharma Kusuma dan TIM. (2012). Pendidikan Karakter kajian Tiori dan Praktek di Sekolah. Bandung: tp.

Novan Andryani. (2013). Konsep, Praktek, dan Strategi Membumikan Karakter di SD. Yogyakarta: tp.

Abdul Majid dan Tim. (2011). Pendidikan Karakter presfektif Islam. Bandung: PT Remaja Rosdakarya.

Maksudin. (2013). Pendidikan Karakter Non-dikotomik. Yogyakarta: Pustaka Belajar.

Sukamto, dkk. (2013). Etika Profesi Berbagai Bidang. Tangerang: Pustaka Mandiri.

John Deigh in Robert Audi (ed). (1995). The cambridge Dictionary of Philisophy. London: The Cambridge Dictionaryof Philosophy.

Ade Dewi, dkk. (2013). Modul Pendidikan dan Pelatihan Profesi Guru. Jakarta: Kementrian Pendidikan dan Kebudayaan. 